\title{
Testosterone is Associated with Self-Employment among Australian Men
}

Francis J. Greene $a_{1}{ }^{*}$, Liang Han b, Sean Martin c, Song Zhang b, Gary Wittert c a Birmingham Business School, University of Birmingham, United Kingdom

b Surrey Business School, University of Surrey, United Kingdom

c Discipline of Medicine, University of Adelaide, Australia

* Corresponding Author

\begin{abstract}
Testosterone has pronounced effects on men's physiological development and smaller, more nuanced, impacts on their economic behavior. In this study of 1,199 Australian adult males, we investigate the relationship between the self-employed and their serum testosterone levels. Because prior studies have identified that testosterone is a hormone that is responsive to external factors (e.g. competition, risk-taking), we explicitly control for omitted variable bias and reverse causality by using an instrumental variable approach. We use insulin as our primary instrument to account for endogeneity between testosterone and selfemployment. This is because prior research has identified a relationship between insulin and testosterone but not between insulin and self-employment. Our results show that there is a positive association between total testosterone and self-employment. Robustness checks using bioavailable testosterone and another similar instrument (daily alcohol consumption) confirm this positive finding.
\end{abstract}

JEL Classification: J10, J19

Keywords: testosterone, self-employment, hormones, labor markets

\section{Introduction}

Testosterone, an androgen produced mainly in the testes, has been shown to have pronounced effects on men's physiological development and smaller, more nuanced, associations with economic behavior (Dabbs et al., 1990; Dabbs, 1992). However, alongside cognate genetic research on monozygotic and dizygotic twins (Nicolaou and Shane, 2010; 
Nicolaou et al, 2008), more recent research has begun to identify that individuals with higher levels of testosterone are associated with new venture creation activities (White et al., 2006, 2007) and with behaviours and characteristics commonly associated with selfemployment. Carney and Mason (2010) showed that those with high testosterone levels are more likely to make use of utilitarian decision making. Strong and Dabbs (2000) also found that high testosterone individuals are more likely to be independent, a motive that is characteristic of individuals that are self-employed (Birley and Westhead, 1994; Cassar, 2007). Equally, Cashdan (1995) identified that high testosterone individuals are more selfcentred which relates to findings that the self-employed are more likely to be achievement orientated and focused on their own personal goals (Shane, 2003; Chell, 2008).

We investigate if testosterone levels are associated with self-employment. We focus on self-employment because it differs in one key respect from other labour market states. At its root, indeed the sin non qua of self-employment is that the self-employed are uncertain about their future income (Storey and Greene, 2010). Whilst employees or the unemployed, at least in the short-term, can be fairly certain of their wages or benefits from the state, the self-employed are only certain of their costs. To achieve any income, therefore, the selfemployed are reliant upon their own proactive endeavors.

There are also other reasons for considering that there will be a positive association between testosterone and self-employment. Integral to self-employment is risk-taking behaviour under uncertainty (Kirzner, 1973). Recent cognate research has investigated the link between both organizational and circulating testosterone and financial risk-taking proclivity ${ }^{1}$. Using the ratio of second to fourth finger (2D:4D) as a marker of organizational testosterone, Brañas-Garza and Rustichini (2011) found in their study of 188 college students that lower digit ratio was associated with financial risk-taking in men. These results are similar to that found amongst 413 college students by Stenstrom et al., (2011)

\footnotetext{
${ }^{1}$ Amongst men, testosterone is circulated principally through the testicular Leydig cells. Much of this circulating testosterone, however, is bound to sex hormone-binding globulin. A lesser proportion is not bound to this globulin. This latter type of testosterone is commonly called 'free' or 'bioavailable' testosterone (Kapoor et al., 2005) whilst total testosterone refers to levels of both bound and unbound testosterone. Testosterone can also have organizational effects which persist in the absence of the hormone. Typically, these organizational effects of testosterone occur prenatally or prior to pubescence and lead to masculinization.
} 
who found that rel2 (length of the second finger relative to the sum of the lengths of all four fingers) was associated with financial, social and recreational risk-taking. Using circulating testosterone, Sapienza et al (2009) found that MBA students with higher testosterone levels were more likely to choose a career in finance rather than a less risky career after graduation. Coates and Herbert's (2008) small study of 17 male UK City of London traders also found that morning levels of testosterone were associated with their profitability for that day.

Because self-employment involves proactive behaviors, other studies focused on testosterone's role in competition and status seeking and maintenance also provide clues as to why testosterone may be associated with self-employment. Competition studies (Archer, 2006) generally indicate that actual or prospective competitive activities lead to changes in testosterone levels (Fry et al., 2011; van der Meij et al, 2012) whilst Saad and Vongas (2009) found that testosterone levels were linked to displays of social status: men that drove a Porsche had higher testosterone levels than when they drove a lower status vehicle such as a family sedan.

Overall, given the direct evidence of a link between testosterone and self-employment (White et al., 2006, 2007) and cognate evidence that links testosterone with risk-taking and agentic behaviors (Archer, 2006; Sellers et al., 2007; Zyphur et al., 2009), we hypothesize that higher serum testosterone levels in men is associated with being self-employed particularly compared with those in employment but also potentially those that are unemployed and inactive in the labour market.

In doing so, we are conscious of two issues. First, we are unaware of any other large scale community based study that specifically examines the effect of testosterone on selfemployment. Second, the tendency in prior cognate studies has been to assume that because testosterone levels are, in part, heritable (Meikle et al, 1988) then the direction of causation flows from testosterone to the behaviour.

Testosterone, though, is a labile hormone. Studies show that that it changes with age (Gray et al., 1991; Tennekoon \& Karunanay, 1993; Harman et al., 2001); and is influenced by 
environmental conditions. Gray et al., (2006) found testosterone levels to be higher in urban rather than rural dwellers (Saad and Vongas, 2009). Mazur and Booth (1998), Booth et al., (2006) and van Anders and Goldey (2010) also found that higher testosterone levels are more likely amongst divorced and single males than in men who are married. Higher testosterone levels have also been found to be associated with increased alcohol consumption (Lenz et al, 2012). By contrast, further meta-analytic studies have shown that testosterone is inversely related to insulin levels with men with low testosterone levels being more prone to insulin resistance (Grossman, 2011).

This plasticity of testosterone means that even if testosterone levels are higher amongst the self-employed this may not reflect that role occupation has been shown to have a genetic basis (Zhang et al, 2009), particularly in relation to self-employment (Nicolaou et al., 2008). Instead, testosterone may be higher because the self-employed have to take risks and adopt agentic and competitive behaviours in order to survive in self-employment. Cognate research into honor subcultures in the US (Mazur and Booth, 1998) associates higher testosterone levels amongst young black men in communities in which there is a cultural expectation that individuals will adopt a defensive posture to protect their honor or reputation. In short, we cannot ignore, particularly as our data are cross-sectional, the potential for reverse causality.

Our contribution is twofold. First, rather than using samples of particular groups (e.g. MBA students) or small groups of subjects, we use a large representative study of 1,199 adult Australian males from the Florey Adelaide Male Aging Study (FAMAS). We also use blood samples (collected at similar times of the day) of the two types of activational testosterone: total testosterone levels and bioavailable testosterone levels. Second, we use an instrumental variable (IV) approach to control for endogeneity due to omitted variable bias and reverse causality in the relationship between testosterone and self-employment. The rationale for using an IV approach is explained in Section 2. In section 3, we provide an overview of our data and detail the variables used in the study. We then present the results in Section 4 whilst conclusions are presented in Section 5. 


\section{Estimating $T$ and self-employment}

Our outcome variable is an indicator of being self-employed (SE) and we adopt a linear probability model so that:

$$
\operatorname{Prob}(\mathrm{SE}=1)=\Phi\left(\alpha_{0}+\alpha_{1} \mathrm{~T}+\beta^{\prime} X^{\prime}+\mathrm{u}\right)(1)
$$

where $\Phi()$ is the cumulative distribution function of the standard normal distribution. $\operatorname{Prob}(\mathrm{SE}=1)$ here stands for the probability a sample male is self-employed. $T$ is the basal activational testosterone level, $X$ is a vector of explanatory variables and $u$ is the disturbance term. Standard probit ${ }^{2}$ estimates do not generate unbiased results if basal activational testosterone $T$ and the disturbance $u$ are correlated. This is a particular issue in data such as ours that are not experimental. To address these issues, one solution would be to use longitudinal data on basal testosterone to get a better understanding of the activational effects of adult testosterone levels. Another solution is to use a measure of pre-natal testosterone levels (e.g. ratio between second and fourth finger length) to give some indication of the organizational effects of testosterone and examine any potential correlation with current activational testosterone levels. Unfortunately, we do not have finger length ratio variables.

In situations where cross-sectional data are used and there is the potential of omitted variable bias and reverse causality, the standard approach is to use an instrumented variable (IV) approach (Greene, 2003; Pearl, 2000). Adopting an IV approach is advantageous because our data - in common with many other non-experimental data contain only a finite number of variables, and omitted variable bias (variables that are not available in our data) may influence the link between testosterone and self-employment. Similarly, rather than testosterone influencing self-employment, the association may be the other way around (reverse causality). Hence, rather than ignore omitted variable bias (from

\footnotetext{
${ }^{2}$ Following from the nascent evidence base that indicates an association between riskier behaviours and testosterone, we focus on self-employment. We did not use a multinomial approach because of a lack of both theoretical and empirical justification of an association between testosterone and other labour market statuses such as full-time or part-time employment.
} 
some unobserved environmental or genetic factor) or reverse causality (self-employment influences testosterone rather than testosterone influencing self-employment) in the association between testosterone and self-employment, the advantage of the IV approach is that it explicitly controls for these sources of bias and inconsistency in the estimations.

An IV approach is only suitable, in the first stage, if an exogenous variable (i.e. an instrument) can be identified that is, in this context, theoretically and empirically unrelated to selfemployment but theoretically justified and strongly correlated with testosterone (Parker and van Praag, 2006). In other words, for the IV approach to be appropriate, the instrument needs to be a variable that is exogenous to self-employment activity but is statistically and economically correlated with testosterone, the explanatory variable.

In terms of variables that are associated with testosterone, there is now increasing evidence that testosterone is correlated with insulin levels. Observation studies show that there is a significant inverse relationship between testosterone and insulin resistance in men (Andersson et al., 1994; Pitteloud et al., 2005). Nonetheless, other studies have pointed to there being a stronger correlation between insulin and bioavailable testosterone than total testosterone (Rhoden et al., 2005) whilst Pasquali et al (1995) shows that insulin regulates testosterone production. Consistent with our first stage results (Table 3), Seidell et al (1990) reports an inverse relationship between insulin concentration and the total and free levels of testosterone. Alomay et al (2003) also found that when alcohol was given to Wistar rats there was a four-fold increase in their testosterone levels whilst Eriksson et al (1994) and Sarkola and Eriksson (2003) found that alcohol led to increases in human testosterone levels. Overall, these studies show that testosterone is related to insulin and alcohol consumption.

In terms of labour market status, Latif (2009) found (in controlling explicitly for endogeneity) a statistically insignificant relationship between diabetes and male employment outcomes. Moreover, although Tunceli et al (2005) points to diabetics being more likely to be inactive in the labour market, their results showed that the self-employed were no more likely to be diabetic than those in employment. Empirically, we also found that our Hausman and Ftests indicate (Table 2) that endogeneity exists between testosterone and self-employment. This statistically indicates that an IV approach is appropriate. Table 2 also identifies that 
insulin and alcohol are appropriate instruments because, although they are statistically correlated with testosterone (Table 3), they also meet the criteria that they are exogenous to self-employment.

Some explanatory variables of self-employment are also relevant in understanding activational testosterone. For example, those of 'prime age' (30-50 years old) are more likely to be self-employed (Storey and Greene, 2010); confirming a finding that those in this age category are also the most likely to be in full-time work rather than part-time employed or unemployed (Pencavel, 1986). As with the link between testosterone and marital status, married men are more likely to be in employment than either unemployment or outside of the labour market (Pencavel, 1986; Baslevent, 2002; Bonnie, 2003). Married men may also be more likely to be self-employed because they have access to greater pools of capital, relative to single or divorced men, allowing them to more readily become and remain selfemployed (Parker, 2008; Storey and Greene, 2010).

Two other factors commonly associated with self-employment are educational attainment and immigration. There is considerable theoretical and empirical evidence to suggest that immigrants are more likely to become self-employed (Godley, 2001; Hammarstedt, 2001). This may reflect discrimination (Clark and Drinkwater, 1998) or supportive cultural attitudes towards self-employment (Basu and Altinay, 2002). Immigration may also theoretically be linked to testosterone levels - in a similar way to agentic activities such as self-employment - because immigrants are a self-selecting minority. However, given the paucity of research into the relationship between testosterone and self-employment, we are unaware of any empirical work to confirm this relationship.

At a theoretical level, Lucas (1978) suggested that education is likely to have an ambiguous impact on self-employment because whilst increases in the human capital makes individuals more likely to cope with the vicissitudes of self-employment, it also makes them more attractive to employers. A recent meta-analysis (van der Sluis et al., 2005) of empirical research supports this theoretical ambiguity. Again, there is no evidence that we are aware of that would confirm a theoretical or empirical link between education attainment and testosterone. 
Overall, therefore, we adopt an IV approach that uses insulin as the instrumental variable. We also conduct robustness checks on the relationship between testosterone and selfemployment by using bioavailable testosterone as an alternative testosterone measure and daily alcohol consumption as an alternative instrument. Hence, in the second stage, we instrument testosterone (now $\widehat{T}$ ) to provide unbiased estimates.

\section{Data and descriptive statistics}

\subsection{Study overview}

This study uses data from the Florey Adelaide Male Ageing Study which is a representative multi-disciplinary study into the health, lifestyle and economic activities of 1,199 community dwelling randomly selected men, aged 35-81, living in the North Western Suburbs of Adelaide, Australia. Recruitment to the study took place over the period 2002-2005 and involved surveys and clinical visits; all of which were approved by the Royal Adelaide Hospital Research Ethics committee and the Aboriginal Health Research Ethics Committee of South Australia. The response rate was 45.1 per cent (number of participants who attended clinical assessments $(1,195)$ divided by total number of randomly sampled households with eligible participants (2,650). Martin et al., (2007a, b) demonstrated participants were representative of the sampling region and the wider Australian population of men aged 3580 across key demographics (age, region, marital status, educational data and labour market status).

\subsection{Variables}

In terms of the dependent variable, we use self-reported self-employment status. The other labour market states are: retirees, the unemployed, the part-time employed and the fulltime employed. Summary statistics for these variables are presented in Table 1. 
Table 1 about here please

Table 1 also shows that, for testosterone, we have two measures of basal testosterone: plasma total testosterone and plasma bioavailable testosterone. As Diver et al., (2003) indicate that testosterone is subject to a significant diurnal rhythm, blood samples to assess both total and bioavailable testosterone levels were drawn between 8 and 11 am after a 12 hour overnight fast. Total testosterone levels were subsequently determined by chemiluminescent immunoassay using the Immulite 2000 auto analyser (coefficient of variation: $9.3 \%$ at $10.7 \mathrm{nmol} / \mathrm{L}$ concentration). The quoted assay range for total testosterone on the Immulite 2000 is 0.7 to $55 \mathrm{nmol} / \mathrm{L}$, with $0.5 \mathrm{nmol} / \mathrm{L}$ being the lower limit of quantification. Plasma bioavailable testosterone levels were determined by the ammonium sulphate precipitation method (inter-assay coefficient of variation: $3.32 \%$ at $1.38 \mathrm{nmol} / \mathrm{L}$ and $6.15 \%$ at $4.99 \mathrm{nmol} / \mathrm{L}$ ) (Martin et al., 2007a, b; http://www.adelaide.edu.au/mailes).

In terms of controls, we use variables commonly associated with self-employment. We use a dummy for marital status and code it as 1 if the sample is married. Education attainment is captured by a dummy which is coded as 1 if the sample has a university degree. We also control for immigration ( 1 if born in Australia, 0 otherwise) given that immigrants are more likely to become self-employed. As for instrumental variables, we use blood insulin as the primary instrument and daily alcohol consumption as a robustness check.

\section{Results}

\subsection{Instrumental Variable probit estimates}

Given our focus on self-employment, we use an IV probit approach where we compare the effect of total testosterone on self-employment by comparing the self-employed with all of the participants (including retirees) (Model 1); with the unemployed, part and full time employees (Model 2); with part and full-time employees (Model 3) and, finally, by comparing the self-employed with the full-time employed (Model 4). Other than testosterone, we also consider how factors commonly associated with self-employment 
(age ${ }^{3}$, marital status, education attainment and country of birth) impact on self-employment status.

Table 2 reports the IV probit estimates. The first thing to note from Table 2 is that Hausman tests suggest that our IV approach is appropriate and endogeneity exists in the relationship between testosterone and self-employment. This is supported by the fact that our IV estimates are valid if there are no unobserved effects correlated with both our instrument (insulin) and self-employment. Empirically, the F-test results show that the F-statistic varies from 24.01 (Model 4) to 47.01 (Model 1) and are all statistically significant at a 1\% level.

Table 2 also suggests that, out of the control variables, only age is significant. Age plays a significant role in models with restricted samples, suggesting that older males are more likely to be self-employed than younger males. This effect is not significant in Model 1 where we use all samples. This is because participants are dominated by retired males (33.53\% in total) with an average age of 67 . In contrast, those not retired (Model 2) have an average age of 49 .

\section{Table 2 about here please}

The key result, however, of Table 2 is that there is a positive and statistically significant relationship between total testosterone and self-employment across all four models. In short, these results, particularly in terms of the key comparison between the self-employed and the part and full-time employed (Model 3) and full time employed (Model 4) indicate that males with higher total testosterone levels are more likely to be self-employed. In Table 2, we also report the economic effects of total testosterone on the probability of being self-employed. We control all other explanatory variables either at means (age) or median (all others) and investigate the increase of the probability of being self-employed when the total testosterone concentration increases by one standard deviation from the mean. Table 2 shows that with an increase of total testosterone by one standard deviation, the probability of being self-employed increases by $9.97 \%$ in Model 3 and by $13.73 \%$ in Model 4. This is evidence that total testosterone levels are associated both statistically and economically with self-employment.

\footnotetext{
${ }^{3}$ We also considered age square and withdrew it because there is no evidence of non-monotonic effect from age.
} 


\subsection{IV probit first stage results}

Table 3 shows the first stage results of the IV Probit approach. These are important because integral to the IV approach is a necessary first stage to examining the relationship between testosterone and self-employment is that the instrument (insulin) is statistically correlated with the explanatory variable testosterone. If insulin is correlated, then the IV approach is valid, depending, as Table 2 confirmed, on favorable $F$ and Hausman Tests results. Following on from previously, we do not include educational levels as there is no evidence that we are aware of that education is related to testosterone levels. These results show that, as anticipated by prior theory and empirical evidence, males who are older and are married have lower total testosterone levels. Stage one results also indicate that those who are born in Australia have lower testosterone levels. The key finding of Table 3, though, is that insulin is negatively and significantly related to total testosterone, justifying it as a valid instrument.

\section{Table 3 about here please}

\subsection{Robustness checks}

We also conduct two robustness checks to investigate the validity of our above results. First, we use bioavailable testosterone as an alternative measure of testosterone. Given the earlier evidence that bioavailable testosterone levels were strongly correlated with insulin, we re-ran the models in Table 2 to check the robustness of our early findings. The results are reported in the upper panel in Table 4. By considering the same control variables and using insulin as instrument, our results indicate that bioavailable testosterone also has a positive and significant effect on the probability of being self-employed. Similar to our early findings in Table 2, the upper panel of Table 4 also shows that when bioavailable testosterone increases by a standard deviation, the probability of being self-employed increases by $12.22 \%$ in Model 3 and by $16.25 \%$ in Model 4 .

Table 4 about here please 
Second, because the use of insulin as an instrument is novel, we adopt a conservative approach in our robustness checks and use daily alcohol consumption as an alternative instrument ${ }^{4}$. Alcohol is valuable as an instrument because there is evidence that alcohol consumption levels are related to testosterone levels. Lenz et al (2012) show that testosterone has a modifying role in alcohol dependency whilst other studies have identified that those with higher levels of testosterone are more prone to alcohol consumption (La Grange et al., 1995; Eriksson et al., 2005). Again, however, whilst alcohol usage has been linked to poorer employment outcomes (Terza, 2002), there is less evidence that we are aware of to suggest that alcohol usage impacts on self-employment or employment outcomes. Using alcohol as an instrument, we also find that total testosterone is linked positively with self-employment (lower panel, Table 4). This indicates that our primary finding (Table 2) is robust when we use different measures of testosterone and a different instrument to control for endogeneity in the relationship between testosterone and selfemployment ${ }^{5}$.

\section{Conclusions}

To our knowledge, there have been no prior large scale community based studies of the association between testosterone and self-employment ${ }^{6}$. This study hypothesized - based on earlier cognate studies of the association between testosterone and status seeking, competition and risk-taking - that testosterone is associated with self-employment.

\footnotetext{
${ }^{4}$ An alternative approach is to use both insulin and alcohol consumption as testosterone instruments. We did not adopt this approach because first we found that insulin and alcohol consumption are strongly correlated to each other. There is also a determination effect between them and the effect is economically and statistically significant $(p<0.01)$. Because of this effect, when we used both as instruments we found that alcohol consumption has an insignificant coefficient in the models (results are available on request). However, because of the cross-sectional nature of the data, we are not able to investigate the causal relationship between these two possible instruments. Therefore, we use them individually as robustness checks. We also use them individually to avoid the possibility of over-identification.

${ }^{5}$ These multivariate IV results differ from the results from the simple univariate findings of Table 1 which show that the self-employed have lower raw total testosterone levels than other males (13.71 vs. 13.95) but higher raw bioavailable testosterone levels than other males (5.62 vs. 5.03). Key to this paper is the need to control for endogeneity within a multivariate IV framework. Besides the tests outlined in this paper, one further indication of the endogeneity of testosterone is that the first stage IV results showed that the self-employed had, in fact, higher levels of total testosterone than full-time employees (14.64 vs. 14.48).

${ }^{6}$ Earlier studies have tended to be either specific small scale studies of groups of students (White et al, 2006; 2007) or laboratory based studies that focus on the impact of testosterone on animals (Booth et al, 2006).
} 
However, one other contribution of this study is to recognise that basal testosterone either in terms of total or bioavailable testosterone - is labile and it is important to control for endogeneity. The study, therefore, used a two stage IV approach to control for endogeneity.

Using this IV approach with insulin as an instrument, the study examined the association of total testosterone and self-employment using the large-scale FAMAS dataset. This approach is in contrast to earlier studies that have focused on small groups of subjects or particular groups and, typically, have not sought to control for endogeneity. Our IV probit results indicate that there is a positive relationship between total testosterone and selfemployment. Using the alternative measure of testosterone (bioavailable testosterone) and another instrument (alcohol consumption per day) as robustness checks we found a similar positive relationship. Overall, this study found that testosterone levels are associated with the likelihood of being self-employed. An increase in total testosterone levels by a standard deviation increases the probability of self-employment by $10 \%$. For bioavailable testosterone, a standard deviation increases the likelihood of self-employment amongst labour market active males by $12 \%$.

This finding provides succour to the view that testosterone is associated with selfemployment and is in line with other cognate research that has identified that testosterone is associated with risk-taking proclivities and status seeking competition (Archer, 2006). Our results, therefore, contribute to the burgeoning literature that suggests that testosterone in men has a wide-ranging impact on behavior beyond its effects on sex and reproduction.

Our data, though, do not allow us to distinguish if testosterone levels are higher because of risk-taking or status seeking competition. One reason for this is that we do not have a measure of risk-taking. Nor do we have information that considers the relationship between testosterone levels and performance (e.g. income) and particular types of selfemployment (e.g. professional, trade). These are important factors because the status and risk profile of self-employment varies across the self-employment life-cycle (Shane, 2003). For the nascent self-employed (activities associated with becoming self-employed), the typical risk is establishing economic viability of self-employment whilst the status challenge 
is ensuring the social credibility and legitimation of their self-employment (Stinchcombe, 1965). This differs from the actual self-employed (the focus of our study) whose the main challenge is status maintenance and ensuring that costs are lower than revenues (Henley, 2007), or those who have exited self-employment who may have adapt to status loss even if their income - if in employment - is likely to be much more stable (Shepherd, 2003). We, therefore, call on research to use longitudinal data to assess how testosterone changes over time in and out of self-employment; to consider different patterns of self-employment and the specific role that status seeking and risk play in the relationship between testosterone and self-employment.

We also call for consideration of how testosterone levels are influenced by, inter alia, stress levels and hours worked (Smith et al, 2006). This may be particularly pertinent because the self-employed, despite having greater levels of job satisfaction than employees (Benz and Frey, 2008) and evidence that those with elevated testosterone have lower stress reactivity (Hermans et al., 2007), have been found to work relatively longer hours and have greater levels of stress.

Overall, there is a need for much more research in this area, both to investigate if testosterone across the self-employment life-cycle varies and how risk-taking, status seeking and other factors influence testosterone levels. Our hope is that further research can build upon our approach and findings.

In conclusion, this study has sought to examine the association between testosterone and those that are self-employed. Using data on 1,199 Australian males, our two stage IV approach indicate that testosterone is associated with agentic activities such as selfemployment. Whilst such results are novel, we call for further research to tease out how testosterone influences - and is itself influenced - by modern day forms of employment. 


\section{References}

Alomay, A. A., Vallée, M., E O'Dell, L., Koob, G.F., Purdy, R. H., Fitzgerald, R. 2003. Acutely administered ethanol participates in testosterone synthesis and increases testosterone in rat brain. Alcoholism Clinical and Experimental Research 27 1: 38-43.

Andersson, B., Marin, P., Lissner, L., Vermeulen, A., Bjorntorp. P. 1994 Testosterone concentrations in women and men with NIDDM. Diabetes Care 17:405-411.

Apicella, C.L., Dreber, A., Campbell, B., Gray, P.B., Hoffman, M. and Little, A.C. 2008 Testosterone and financial risk preferences. Evolution and Human Behavior 29: 384-390.

Archer, J. 2006 . Testosterone and human aggression: An evaluation of the challenge hypothesis. Neuroscience and Biobehavioral Review 30, 319-345.

Baslevent, C. 2002 Preference of the unemployed between full-time and part-time jobs, Applied Economic Letters 9, 855-7.

Basu, A. and Altinay, E. 2002 The interaction between culture and entrepreneurship in London's immigrant business, International Small Business Journal 204 , 371-94.

Benz, M and Frey, BS. 2008 Being independent is a great thing: Subjective evaluations of self-employment and hierarchy. Economica 75: 362-383.

Birley S and Westhead P. 1994 A Taxonomy of Business Start-up Reasons and Their Impact on Firm Growth and Size. Journal of Business Venturing 9: 7-31.

Bonnie, J. B. 2003 Incidence and duration of unemployment spells: implication on the wage differentials of part-time and full-time workers, Contemporary Economic Policy 21, 227-42. Booth, A., Granger, D.A., Mazur, A. and Kivlighan, K.T. 2006 Testosterone and social behavior. Social Forces 85: 167-191.

Brañas-Garza P, Rustichini A 2011 Organizing Effects of Testosterone and Economic Behavior: Not Just Risk Taking. PLoS ONE 6 12: e29842. 
Carney, D.R. and Mason, M.F. 2010 Decision making and testosterone: When the ends justify the means. Journal of Experimental Social Psychology 46: 668-671.

Cashdan, E. A. 1995 Hormones, sex, and status in women. Hormones and Behavior 29, 354366.

Cassar G. 2007 Money, money, money? A longitudinal investigation of entrepreneur career reasons, growth preferences and achieved growth. Entrepreneurship and Regional Development 19: 89-107.

Chell, E. 2008 The entrepreneurial personality: a social construction London: Routledge. Clark K and Drinkwater S. 1998 Ethnicity and self-employment in Britain. Oxford Bulletin of Economics and Statistics 60: 383-395.

Coates JM and Herbert J. 2008 Endogenous steroids and financial risk taking on a London, trading floor. Proceedings of the National Academy of Sciences of the United States of America 105: 6167-6172.

Dabbs, J. M., Delarue, D., \& Williams, P. M. 1990 . Testosterone and occupational choice actors, ministers, and other men. Journal of Personality and Social Psychology 59 6, 12611265.

Dabbs, J. M. 1992 . Testosterone and occupational achievement. Social Forces 70:3 813-824. Diver MJ, Imtiaz KE, Ahmad AM 2003 Diurnal rhythms of serum total, free and bioavailable testosterone and of SHBG in middle-aged men compared with those in young men. Clinical Endocrinology 58: 710-717.

Eriksson, C.J.P., Fukunaga, T., Lindman, R. 1994 Sex hormone response to alcohol. Nature 369, 711. 
Eriksson, C.J.P., Kaprio, J., Pulkkinen, L., Rose, R.J., 2005 Testosterone and alcohol use among adolescent male twins: testing between-family associations in withinfamily comparisons. Behavioral Genetics 35, 359-368.

Fry, A.C., Schilling, B.K., Fleck, S.J. and Kraemer, W.J. 2011 Relationships between competitive wrestling success and neuroendocrine responses. Journal of Strength and Conditioning Research 25: 40-45.

Godley, A. 2001 Jewish Immigrant Entrepreneurship in New York and London, 1880-1914: Enterprise and Culture Palgrave, Basingstoke.

Gray, P.B., Kruger, A., Huisman, H.W. , Wissing, M.P. and Vorster, H.H. 2006 Predictors of south African male testosterone levels: The THUSA study. American Journal of Human Biology 18: 123-132.

Gray, A., Berlin, J.A., McKinlay, J.B. \& Longcope, C. 1991 An examination of research design effects on the association of testosterone and male aging: results of a meta-analysis. Journal of Clinical Epidemiology 44, 671-684.

Greene, W. 2003 Econometrics London: Prentice Hall.

Grossmann, M. 2011. Low Testosterone in Men with Type 2 Diabetes: Significance and Treatment. Journal of Clinical Endocrinology \& Metabolism 96:8, 2341-2353.

Hammarstedt M. 2001 Immigrant self-employment in Sweden - its variation and some possible determinants. Entrepreneurship and Regional Development 13: 147-161.

Harman, S.M., Metter, J.E., Tobin, J.D., Pearson, J. \& Blackman, M.R. 2001 Longitudinal effects of aging on serum total and free testosterone levels in healthy men. Journal of Clinical Endocrinology and Metabolism 86, 724-731.

Henley, A. 2007 . Entrepreneurial aspiration and transition into self-employment: evidence from British longitudinal data. Entrepreneurship and Regional Development 19:3, 253-280. 
Hermans EJ, Putman P, Baas JM 2007 Exogenous testosterone attenuates the integrated central stress response in healthy young women. Psychoneuroendocrinology 32: 1052-1061. Kapoor, D, Malkin, CJ Channert, KS, Jones, TH. 2005. Androgens, insulin resistance and vascular disease in men. Clinical Endocrinology. 63: 239-250.

La Grange, L., Jones, T.D., Erb, L., Reyes, E., 1995 Alcohol consumption: biochemical and personality correlates in a college student population. Addictive Behavior 20, 93-103.

Latif, E. 2009 . The Impact of Diabetes on Employment in Canada. Health Economics 18: 5, 577-589.

Lenz, B., Muller, C. P., Stoessel, C., Sperling, W., Biermann, T., Hillemacher, T., Kornhuber, J. 2012 Sex hormone activity in alcohol addiction: Integrating organizational and activational effects. Progress in Neurobiology 96:1, 136-163.

Lucas, R.E. 1978 'On the Size Distribution of Business Firms', Bell Journal of Economics 9, 508-523.

Martin, S., Haren, M., Taylor, A., Middleton, S., and Wittert, G. 2007a The Florey Adelaide Male Ageing Study FAMAS : Design, procedures \& participants, School of Medicine, University of Adelaide: Adelaide.

Martin, S., Haren, M., Taylor, A., Middleton, S., and Wittert, G. 2007b Cohort profile: The Florey Adelaide Male Ageing Study FAMAS . International Journal of Epidemiology 36: 302306.

Mazur, A. and Booth, A. 1998 Testosterone and dominance in men. Behavioral and Brain Sciences 21: 353-389.

Mazur, A., Booth, A. and Dabbs, J.M. 1992 Testosterone and Chess Competition. Social Psychology Quarterly 55: 70-77. 
Meikle, A.W., Stringham, J.D., Bishop, D.T., and West, D.W. 1988. Quantitating genetic and nongenetic factors influencing androgen production and clearance rates in men. Journal of Clinical Endocrinology and Metabolism 67, 104-109.

Nicolaou, N., \& Shane, S. 2010 . Entrepreneurship and occupational choice: Genetic and environmental influences. Journal of Economic Behavior \& Organization 76:1, 3-14.

Nicolaou N, Shane S, Cherkas L, Hunkin, J. and Spector, T.D. 2008 Is the tendency to engage in entrepreneurship genetic? Management Science 54: 167-179.

Parker SC. 2008 Entrepreneurship among married couples in the United States: A simultaneous probit approach. Labour Economics 15: 459-481.

Parker, S.C. and Van Praag, C.M. 2006 Schooling, capital constraints, and entrepreneurial performance: the endogenous triangle. Journal of Business \& Economic Statistics 24: 416431.

Pasquali R., Casimirri F., De lasio R., Mesini P., Boschi S., Chierici R., Flamia R., Biscotti M., Vicennati V. 1995 Insulin regulates testosterone and sex hormone-binding globulin concentrations in adult normal weight and obese men. Journal of Clinical Endocrinology and Mctabolism 80:2 654-658.

Pearl, J. 2000 Causality: Models, Reasoning and Inference Cambridge: Cambridge University Press.

Pencavel, J. 1986 Labour supply of men: a survey, in Handbook of Labour Economics Vol. 1 Eds O. Ashenfelter and R. Layard, Elsevier Science Publishers, Amsterdam.

Pitteloud N., Mootha V.K., Dwyer A.A., Hardin M., Lee H., Eriksson K.F., Tripathy D., Yialamas M.., Groop L., Elahi D., Hayes F.J. 2005 Relationship between testosterone levels, insulin sensitivity, and mitochondrial function in men. Diabetes Care. 28: 1636-1642. 
Rhoden E.L., Ribeiro E.P., Teloken C., Souto C.A. 2005 Diabetes mellitus is associated with subnormal serum levels of free testosterone in men. BJU International 96:867-870.

Saad, G. and Vongas, J.G. 2009 The effect of conspicuous consumption on men's testosterone levels. Organizational Behavior and Human Decision Processes 110: 80-92.

Sapienza, P., Zingales, L. and Maestripieri, D. 2009 Gender differences in financial risk aversion and career choices are affected by testosterone. Proceedings of the National Academy of Sciences of the United States of America 106: 15268-15273.

Sarkola, T. and Eriksson, C.J.P. 2003 Testosterone Increases in Men After a Low Dose of Alcohol. Alcoholism: Clinical and Experimental Research 27: 682-685.

Seidell, J.C., Björntorpa, P., Sjöströma, L, Kvist, H. and Sannerstedt, R. 1990 Visceral fat accumulation in men is positively associated with insulin, glucose, and C-peptide levels, but negatively with testosterone levels. Metabolism 39, 897-901.

Sellers J.G., Mehl M.R. and Josephs R.A. 2007 Hormones and personality: Testosterone as a marker of individual differences. Journal of Research in Personality 41: 126-138.

Shane, S. 2003 : A General Theory of Entrepreneurship. The Individual-Opportunity Nexus, Cheltenham: Edward Elgar, 2003.

Shepherd, D.A. 2003 Learning from business failure: Propositions of grief recovery for the self-employed. Academy of Management Review 28: 2, 318-328.

Smith A.M., Morris P., Rowell K.O., Clarke S., Jones T.H. and Channer K.S. 2006 Junior doctors and the full shift rota - psychological and hormonal changes: a comparative crosssectional study. Clinical Medicine 6: 174-177.

Stanton, S.J., Liening, S.H., and Schultheiss, O.C. 2011 Testosterone is positively associated with risk taking in the lowa Gambling Task. Hormones and Behavior 59: 252-256. 
Stenstrom, E., Saad, G., Nepomuceno, M. V., \& Mendenhall, Z. 2011 Testosterone and domain-specific risk: Digit ratios 2D:4D and rel2 as predictors of recreational, financial, and social risk-taking behaviors. Personality and Individual Differences 51:4 , 412-416.

Storey, D.J. and Greene, F.J. 2010 Small Business and Entrepreneurship London: Pearson/FT.

Stinchcombe, A.L. 1965. 'Social structure and organizations.' In J.G. March, ed., Handbook of Organizations Chicago: Rand McNally Publishers: 142-193.

Strong, R. K., and Dabbs, J. M. 2000 Testosterone and behaviour in normal young children. Personality and Individual Differences 28, 909-915.

Tennekoon, K.H. and Karunanayake, E.H. 1993 Serum FSH, LH and testosterone concentrations in presumably fertile men; effect of age. International Journal of Fertility 38, 108-112.

Terza JV. 2002 Alcohol abuse and employment: a second look. Journal of Applied Econometrics 17: 393-404.

Tunceli, K., Bradley, C. J., Nerenz, D., Williams, L. K., Pladevall, M., \& Lafata, J. E. 2005 The impact of diabetes on employment and work productivity. [Article]. Diabetes Care 28:11, 2662-2667.

van Anders, S.M. and Goldey, K.L. 2010 Testosterone and partnering are linked via relationship status for women and 'relationship orientation' for men. Hormones and Behavior 58: 820-826.

van der Meij, L., Almela, M., Hidalgo, V., Villada, C., Ijzerman, H., van Lange, P. A. M., and Salvador, A. 2012 . Testosterone and Cortisol Release among Spanish Soccer Fans Watching the 2010 World Cup Final. Plos One 7: 4, e34814 . 
Wingfield J.C., Hegner R.E., Dufty A.M., 1990 The challenge hypothesis - theoretical implications for patterns of testosterone secretion, mating systems, and breeding strategies. American Naturalist 136: 829-846.

White, R.E., Thornhill, S. and Hampson, E. 2006 Entrepreneurs and evolutionary biology: The relationship between testosterone and new venture creation. Organizational Behavior and Human Decision Processes 100: 21-34.

White, R.E., Thornhill, S. and Hampson, E. 2007 A biosocial model of entrepreneurship: the combined effects of nurture and nature. Journal of Organizational Behavior 28: 451-466.

Zhang Z., Zyphur M.J., Narayanan J. 2009 The genetic basis of entrepreneurship: Effects of gender and personality. Organizational Behavior and Human Decision Processes 110: 93-107. Zyphur M.J., Narayanan J., Koh G., and Koh D. 2009 Testosterone-status mismatch lowers collective efficacy in groups: Evidence from a slope-as-predictor multilevel structural equation model. Organizational Behavior and Human Decision Processes 110: 70-79. 
Table 1: Descriptive Statistics (Variables, Percentages, Means and Standard Deviations)

\begin{tabular}{lcccccc}
\hline & All & $\begin{array}{c}\text { Full-time } \\
\text { employes }\end{array}$ & $\begin{array}{c}\text { Part time } \\
\text { employees }\end{array}$ & $\begin{array}{c}\text { Self- } \\
\text { employed }\end{array}$ & Unemployed & Retired \\
\hline Total Testosterone (TT: & 13.95 & 14.22 & 15.37 & 13.71 & 15.56 & 13.00 \\
nmol/L) & $(5.50)$ & $(4.99)$ & $(5.85)$ & $(4.76)$ & $(7.07)$ & $(5.82)$ \\
Bioavailable Testostorone & 5.03 & 5.48 & 5.55 & 5.62 & 5.38 & 4.13 \\
(BT: nmol/L) & $(1.89)$ & $(1.84)$ & $(2.04)$ & $(1.94)$ & $(2.31)$ & $(1.51)$ \\
Married (1= married, 0= & $81 \%$ & $86 \%$ & $75 \%$ & $76 \%$ & $63 \%$ & $79 \%$ \\
otherwise: \%) & $(39 \%)$ & $(35 \%)$ & $(44 \%)$ & $(43 \%)$ & $(49 \%)$ & $(41 \%)$ \\
& 55.10 & 48.34 & 52.58 & 51.34 & 51.04 & 66.81 \\
Age (years) & $(11.66)$ & $(7.80)$ & $(9.19)$ & $(10.07)$ & $(9.37)$ & $(7.89)$ \\
Degree (1=degree and & $12 \%$ & $15 \%$ & $14 \%$ & $17 \%$ & $10 \%$ & $6 \%$ \\
above, 0 otherwise: \%) & $(32 \%)$ & $(36 \%)$ & $(34 \%)$ & $(38 \%)$ & $(31 \%)$ & $(25 \%)$ \\
Country of birth (1= Born in & $67 \%$ & $70 \%$ & $73 \%$ & $66 \%$ & $65 \%$ & $61 \%$ \\
Australia, 0= otherwise: \%) & $(47 \%)$ & $(46 \%)$ & $(45 \%)$ & $(48 \%)$ & $(48 \%)$ & $(49 \%)$ \\
Insulin ( $\mu$ lU/mL) & 11.07 & 10.71 & 9.30 & 9.00 & 12.06 & 12.18 \\
Alcohol consumption & $(9.40)$ & $(8.43)$ & $(6.22)$ & $(5.23)$ & $(17.82)$ & $(10.26)$ \\
(g/day) & 19.57 & 21.64 & 20.77 & 26.51 & 19.08 & 15.47 \\
Number of observations & $(21.67)$ & $(21.58)$ & $(24.52)$ & $(23.69)$ & $(23.65)$ & $(19.88)$ \\
\hline Not & 1199 & 597 & 111 & 41 & 48 & 402 \\
\hline
\end{tabular}

Note: Total number of observations is 1,199, including $49.79 \%$ full-time employees, $9.26 \%$ part-time employees, $3.42 \%$ self-employed, $4 \%$ unemployed and $33.53 \%$ retired. Percentages and means are reported with standard deviations in parentheses 
Table 2: IV Probit estimates (dependent variable: being self-employed)

\begin{tabular}{|c|c|c|c|c|}
\hline & $\begin{array}{c}\text { Model } 1 \\
\text { (all samples } \\
\text { including retirees) }\end{array}$ & $\begin{array}{c}\text { Model } 2 \\
\text { (unemployed, part } \\
\text { \& full-time } \\
\text { employed) }\end{array}$ & $\begin{array}{c}\text { Model } 3 \\
\text { (part \& full time } \\
\text { employees) }\end{array}$ & $\begin{array}{c}\text { Model } 4 \\
\text { (full-time employees) }\end{array}$ \\
\hline \multirow{2}{*}{$\begin{array}{l}\text { Total testosterone } \\
\text { (IV=insulin) }\end{array}$} & $0.11^{* *}$ & $0.10^{*}$ & $0.09^{*}$ & $0.11^{* *}$ \\
\hline & $(0.04)$ & $(0.05)$ & $(0.06)$ & $(0.06)$ \\
\hline \multirow{2}{*}{ Age } & 0.00 & $0.02^{* *}$ & $0.02^{* *}$ & $0.03^{* * *}$ \\
\hline & $(0.01)$ & $(0.01)$ & $(0.01)$ & $(0.01)$ \\
\hline \multirow{2}{*}{ Married } & 0.14 & 0.11 & -0.03 & -0.05 \\
\hline & $(0.18)$ & $(0.25)$ & $(0.24)$ & $(0.26)$ \\
\hline \multirow{2}{*}{ Degree } & 0.11 & 0.09 & 0.08 & 0.08 \\
\hline & $(0.15)$ & $(0.16)$ & $(0.17)$ & $(0.17)$ \\
\hline \multirow{2}{*}{ Country of birth } & 0.02 & 0.04 & 0.04 & 0.09 \\
\hline & $(0.12)$ & $(0.14)$ & $(0.16)$ & $(0.16)$ \\
\hline \multirow{2}{*}{ Constant } & $-3.14^{* * *}$ & $-3.91^{* * *}$ & -3.73 & $-4.13^{* * *}$ \\
\hline & $(0.85)$ & $(0.90)$ & $(0.96)$ & $(0.88)$ \\
\hline No. of observations & 1193 & 795 & 747 & 636 \\
\hline Log pseudo likelihood & -3835.57 & -2561.53 & -2396.30 & -2038.19 \\
\hline Wald Chi2 & $22.35^{* * *}$ & $10.36^{*}$ & $10.40^{*}$ & $16.64^{* * *}$ \\
\hline Hausman Exogeneity Chi2 & $4.61^{* *}$ & $3.27^{*}$ & $3.01^{*}$ & $3.37^{*}$ \\
\hline$\Delta \operatorname{Prob}(\mathrm{SE}=1 \mid \Delta \mathrm{TT}=\sigma)$ & $11.01 \%$ & $10.80 \%$ & $9.97 \%$ & $13.73 \%$ \\
\hline $1^{\text {st }}$ stage F Stat & $35.26^{* * *}$ & $23.16^{* * *}$ & $19.12^{* * *}$ & $15.46^{* * *}$ \\
\hline Weak instrument $\mathrm{F}$ test & $47.01^{* * *}$ & $31.04^{* * *}$ & $30.10^{* * *}$ & $24.01^{* * *}$ \\
\hline
\end{tabular}

Notes: standard error is in parentheses. ${ }^{*}, * *$ and $* * *$ indicate $10 \%, 5 \%$ and $1 \%$ significance level respectively. 
Table 3: IV Probit first stage results (endogenous variable: total T)

\begin{tabular}{|c|c|c|c|c|}
\hline & $\begin{array}{c}\text { Model } 1 \\
\text { (all samples } \\
\text { including retirees) }\end{array}$ & $\begin{array}{c}\text { Model } 2 \\
\text { (unemployed, part } \\
\text { \& full-time } \\
\text { employed) }\end{array}$ & $\begin{array}{c}\text { Model } 3 \\
\text { (part \& full time } \\
\text { employees) }\end{array}$ & $\begin{array}{c}\text { Model } 4 \\
\text { (full-time employees) }\end{array}$ \\
\hline Age & $\begin{array}{c}-0.09^{* * *} \\
(0.01)\end{array}$ & $\begin{array}{c}-0.07^{* * *} \\
(0.02)\end{array}$ & $\begin{array}{c}-0.06^{* * *} \\
(0.02)\end{array}$ & $\begin{array}{c}-0.06^{* *} \\
(0.02)\end{array}$ \\
\hline Married & $\begin{array}{c}-2.04^{* * *} \\
(0.44)\end{array}$ & $\begin{array}{c}-2.69^{* * *} \\
(0.53)\end{array}$ & $\begin{array}{c}-2.09^{* * *} \\
(0.52)\end{array}$ & $\begin{array}{c}-2.10^{* * *} \\
(0.61)\end{array}$ \\
\hline Country of birth & $\begin{array}{c}-0.60^{* *} \\
(0.31)\end{array}$ & $\begin{array}{c}-0.91^{* *} \\
(0.38)\end{array}$ & $\begin{array}{c}-1.02^{* * *} \\
(0.40)\end{array}$ & $\begin{array}{c}-1.12^{* * *} \\
(0.41)\end{array}$ \\
\hline Insulin & $\begin{array}{l}-0.11^{* * *} \\
(0.02)\end{array}$ & $\begin{array}{c}-0.12^{* * *} \\
(0.02)\end{array}$ & $\begin{array}{c}-0.14^{* * *} \\
(0.03)\end{array}$ & $\begin{array}{c}-0.12^{* * *} \\
(0.03)\end{array}$ \\
\hline Constant & $\begin{array}{c}22.06^{* * *} \\
(0.85)\end{array}$ & $\begin{array}{c}21.82^{* * *} \\
(1.11)\end{array}$ & $\begin{array}{c}21.41^{* * *} \\
(1.14)\end{array}$ & $\begin{array}{c}20.79^{* * *} \\
(1.18)\end{array}$ \\
\hline
\end{tabular}

Notes: standard error is in parentheses. ${ }^{*}, * *$ and $* * *$ indicate $10 \%, 5 \%$ and $1 \%$ significance level respectively 
Table 4: Robustness check (upper panel: bioavailable testosterone instrumented by insulin; lower panel: total testosterone instrumented by daily alcohol consumption)

\begin{tabular}{|c|c|c|c|c|c|}
\hline & & $\begin{array}{c}\text { Model } 1 \\
\text { (all samples) }\end{array}$ & $\begin{array}{c}\text { Model } 2 \\
\text { (retired samples } \\
\text { excluded) }\end{array}$ & $\begin{array}{c}\text { Model } 3 \\
\text { (retired and } \\
\text { inactive samples } \\
\text { excluded) }\end{array}$ & $\begin{array}{c}\text { Model } 4 \\
\text { (only full time } \\
\text { and self- } \\
\text { employed } \\
\text { included) }\end{array}$ \\
\hline & $\begin{array}{l}\text { Bioavailable testosterone } \\
\text { (instrumented by insulin) }\end{array}$ & $\begin{array}{c}0.44^{* * *} \\
(0.14)\end{array}$ & $\begin{array}{l}0.41^{* *} \\
(0.16)\end{array}$ & $\begin{array}{l}0.38^{* *} \\
(0.18)\end{array}$ & $\begin{array}{l}0.45^{* * *} \\
(0.16)\end{array}$ \\
\hline \multirow[t]{4}{*}{$\begin{array}{l}\text { Upper } \\
\text { Panel }\end{array}$} & $\Delta \operatorname{Prob}(\mathrm{SE}=1 \mid \Delta \mathrm{BT}=\sigma)$ & $2.18 \%$ & $12.99 \%$ & $12.22 \%$ & $16.25 \%$ \\
\hline & $1^{\text {st }}$ stage F Stat & $104.15^{* * *}$ & $42.89^{* * *}$ & $38.18^{* * *}$ & $34.58^{* * *}$ \\
\hline & Weak instrument $\mathrm{F}$ test & $41.86^{* * *}$ & $27.14^{* * *}$ & $31.79^{* * *}$ & $26.53^{* * *}$ \\
\hline & No. of Obs & 1192 & 795 & 747 & 636 \\
\hline \multirow[t]{2}{*}{$\begin{array}{l}\text { Lower } \\
\text { Panel }\end{array}$} & $\begin{array}{l}\text { Total testosterone } \\
\text { (instrumented by daily } \\
\text { alcohol consumption) }\end{array}$ & $\begin{array}{l}0.16^{* * *} \\
(0.03)\end{array}$ & $\begin{array}{l}0.18^{* * *} \\
(0.03)\end{array}$ & $\begin{array}{l}0.19^{* * *} \\
(0.03)\end{array}$ & $\begin{array}{c}0.20^{* * *} \\
(0.02)\end{array}$ \\
\hline & $\Delta \operatorname{Prob}(\mathrm{SE}=1 \mid \Delta \mathrm{TT}=\sigma)$ & $22.65 \%$ & $31.72 \%$ & $35.52 \%$ & $39.31 \%$ \\
\hline
\end{tabular}

Notes: All estimates include age, married, degree and country of birth dummies. Standard error is in parentheses. ${ }^{*}, * *$ and *** indicate $10 \%, 5 \%$ and $1 \%$ significance level respectively 